\title{
Comparission of Smear Examination and Cell Block in Efussions
}

\author{
Dr. Rondla Madhavi Reddy ${ }^{1}$, Jilla Rajitha ${ }^{2 *}$
}

\author{
${ }^{1}$ Assistant Professor, Department of Pathology, MNR Medical College, Sangareddy, Hyderabad, Telangana, 502294, India \\ ${ }^{2}$ Associate Professor, Department of Pathology, Chalmeda Anand Rao Institute of Medical Sciences, Bommakal, Karimnagar, Telangana, 505001, \\ India
}

DOI: $10.36347 /$ sjams.2021.v09i01.011

| Received: 21.12.2020 | Accepted: 07.01.2021 | Published: 11.01.2021

*Corresponding author: Dr. Jilla Rajitha

Abstract

Original Research Article

Aim: To assess the efficacy of cell block versus smear examination in effusion. To assess the utility of the cell block preparation method in increasing the sensitivity of cytodiagnosis of effusions \& to evaluate the primary site malignant effusions wherever needed with the help of immunohistochemistry. Materials $\&$ Methods: A total of 120 fluid samples were subjected to evaluation by both Smear examination and Cell Block methods over a period of 2 years. Cellularity, architecture patterns, morphological features and yield for malignancy were compared, using the two methods. Results: Out of 120 cases, 12 cases were found be malignant effusions. Among 120 cases 95 pleural,18 peritoneal,7 pericardial effusions. Cell Block method provided higher cellularity, better architectural patterns and additional yield for malignancy as compared to Smear examination method. Using a combination of the cell block \& smear technique yielded 3 more malignant cases than what were detected using smears by themselves. Conclusion: Cell block technique provides high cellularity, better architectural pattern, morphological features \& an additional yield of malignant cells \& thereby increasing the sensitivity of the cytodiagnosis when compared with cytosmear technique.it is advisable to routinely make Cell Blocks before discarding specimens that are suspicious for malignancy by smear examination.

Keywords: Cell block, cytodiagnosis and immunohistochemistry.

Copyright $\left({ }_{0} 2021\right.$ The Author(s): This is an open-access article distributed under the terms of the Creative Commons Attribution 4.0 International License (CC BY-NC 4.0) which permits unrestricted use, distribution, and reproduction in any medium for non-commercial use provided the original author and source are credited.

\section{INTRODUCTION}

Serous inflammation is marked by presence of a thin fluid that may be derived from the plasma or from the mesothelial cells lining the peritoneal, pleural or pericardial cavities [1]

Cytological examination of serous fluids is of paramount importance not only in detecting cancer cells, but it also reveals information regarding various inflammatory conditions of serous membranes, various bacterial, viral, fungal infections and parasitic infestations [2].

Accurate identification of malignant or reactive mesothelial cells is a diagnostic problem in conventional cytological smears. Cytodiagnosis by conventional smears have got lower sensitivity due to overcrowding of cells, cell loss and different laboratory processing methods [3].

Most of the fluids received in the cytology laboratory contain blood clots or small bits of tissue from the lesion. While preparing the slide they remain in bottle and are not available for microscopy. Cellblocks are also particularly useful when samples are heavily admixed with blood. Smears may show only blood and a few distorted cells. Surprisingly, good tissue fragments may be found in sections of the cell block [4].

Apart from increased cellularity, better morphological details are obtained by cell block method which include preservation of the architectural pattern like cell balls and papillae and three dimensional clusters, better nuclear and cytoplasmic preservation, intact cell membrane and chromatin details [5]. Cell block method has many advantages like multiple sections of the same material can be obtained for special stains and immunohistochemistry.

Fluids which are received in the laboratory are evaluated in the form of physical, chemical and microscopic examinations. Physical examination includes volume, color and appearance. Chemical examination includes sugars, Proteins, Enzymes (LDH, 
ADA) Specific Gravity, PH, C-reactive protein, lipid analysis. For microscopy fluids are examined under the microscopy are in the form of cytosmears \& cell block [6].

\section{Materials and Methods}

This diagnostic evaluation study was carried out in the Central Laboratory, department of pathology, in a tertiary care hospital, Sangareddy. The present study was done for a period of two years from febuary 2018 to January 2020. During this period, pleural, peritoneal and pericardial fluids obtained by aspiration were analysed. Ananalys is of 150 cases of various lesions of pleural, peritoneal and pericardial fluids during this period was done.

After clinical, biochemical and radiological investigation, fluids thus obtained were first examined grossly for volume, color and appearance and findings were noted.

Processing of Fluids: The fluids were divided into two equal parts. One part was kept for smear examination and the other part for cellblock.

Centrifuged Smear: Thoroughly mixed half of the specimen centrifuged at $1500 \mathrm{rpm}$ for $15 \mathrm{~min}$. Supernatant is discarded from that sediment. Smears are prepared and stained with Haematoxylin \& Eosin and Romanowsky.

\section{Cell Block Technique}

- The other half of the fluid specimen is centrifuged at $2500 \mathrm{rpm}$ for $10-15 \mathrm{~min}$. The supernatant fluid is discarded following which a cell button is formed, to it, 2 to 3 drops of out dated plasma, 2to3 drops of thromboplastin and 2to3 drops of calcium chloride are added and allowed to clot. Cell button along with the clot is formed which is then fixed in $10 \%$ Buffered formalin for 24 hours.

- Cell button with the clot is wrapped in a filter paper and processed in tissue processor. Cell block is prepared after embedding it in paraffin medium. Sections are cut and stained with Hematoxylin and Eosin. Special stains including, Periodic acid stain were done when needed.

- The slides were carefully evaluated for the following features: Background of the smear/cell block, predominant cell type, presence of aggregated/isolated cells, predominant pattern of aggregate-spherules, loose clusters etc. presence of patterns such as Indian file arrangement, rosettes and acini, uniformity or pleomorphism, presence of vacuolated cells, presence of any irregularity nuclear membranes and chromatic pattern, presence/absence of nucleoli, abnormal mitosis, presence of any Multi nucleated cells/giant cells, presence of any other reactive/stromal elements. A comparative evaluation of smear versus cell block technique was done.

\section{RESULTS}

From Febuary 2018 to January 2020, 190 samples of various fluids were received. We have studied 150 fluids for present study which constitutes $78 \%$ of total fluids. Among total no. of 150 fluids, 122 $(81.3 \%)$ pleural, $23(15.35 \%)$ peritoneal, $5(3.33 \%)$ pericardial fluids.

In a total of 150 fluids, most of the patients between 41-50 years constituting 38 cases $(25.3 \%)$. In this study most of the patients were males when compared to females, male to female ratio is $2.57: 1$. In a total of 150 fluids received, males were $108(72 \%)$ and $42(28 \%)$ were females.

Out of 122 pleural fluids, 75 cases showed lymphocytes by cell block technique in which 75 cases showed lymphocytes on smear examination.3 cases showed scant cellularity on cytosmears which shows mixed inflammatory cells \& lymohocytes in cell block. 2 cases of suspicious for malignancy by smear showed malignancy by cell block technique (Figure-1). One of the pleura fluid cell block showed microfilaria (WucherariaBrancrofti), which was missed on cytosmears (Figure-2). Table-1 shows comparision of smears with cell block in various fluids.

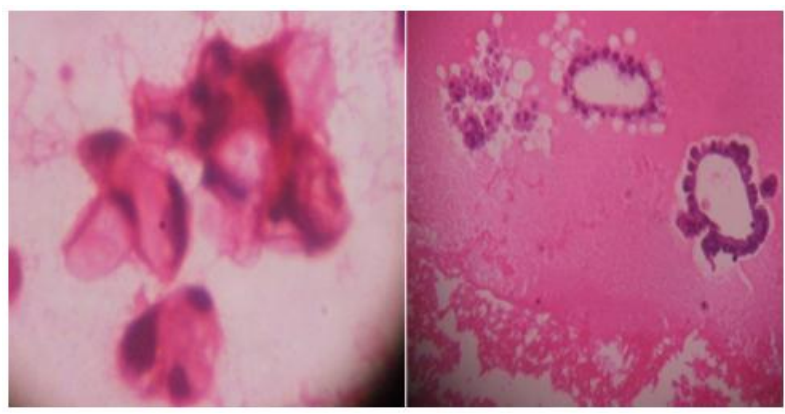

Fig-1: (a) Smears showing pleomprphic cells with eccentrically placed nuclei; Pleural fluid (H\&Estain, 40X). (b) Cell block showing cells are arranged in acinar pattern Pleural fluid (H\&Estain, 10X)

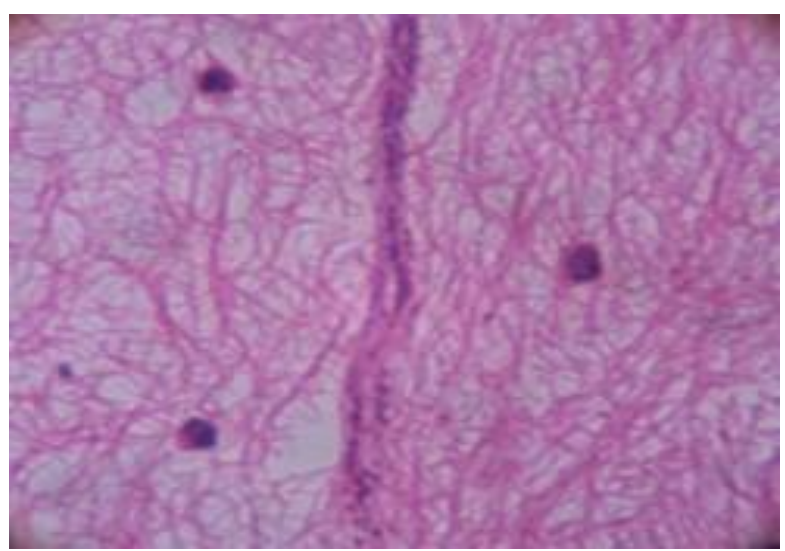

Fig-2: Cell block showing microfilaria Pleural fluid (H\&E stain,10X) 
Table-1: Efficacy of Centrifuged smears with cell block in detecting malignant cells

\begin{tabular}{|l|l|l|l|}
\hline \multicolumn{2}{|l|}{ Cell block } & Total \\
\hline Cytosmears & Positive for malignant cells & Negative for malignant cells & \\
\hline Positive for malignant cells & 13 & 0 & 13 \\
\hline Negative for malignant cells & 03 & 134 & 136 \\
\hline Total & 16 & 134 & 150 \\
\hline
\end{tabular}

Sensitivity $=81.25 \%$

Specificity $=100 \%$

Positive predictive value $=100 \%$

Negative predictive value $=97.81 \%$

Accuracy $=98 \%$
Out of 23 peritoneal fluids, 12cases showed lymphocytes by cell block technique as well as in cytology. On cytosmears scant cellularity noted in a case, where as cell block showed mixed inflammatorycells.1case of suspicious for malignancy by smear showed malignancy by cell block technique (Figure $2 \& 3$ ).

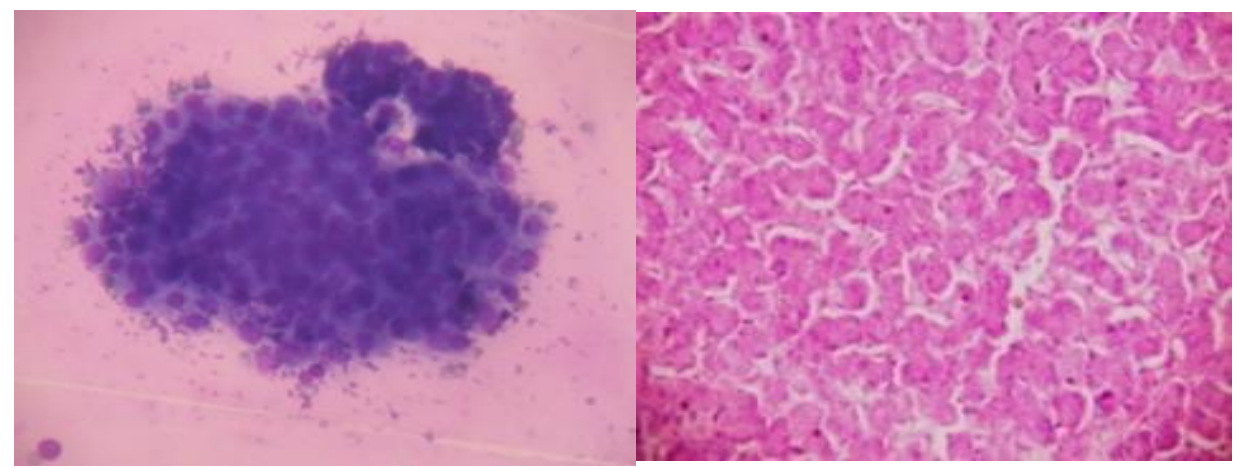

Fig-2: (a) Smears showing malignant cells in Peritoneal fluid (Leishman stain, 40X). (b) Cell block showing malignant cells arranged in acinar formations; Peritoneal fluid (H\&E stain, 10X)

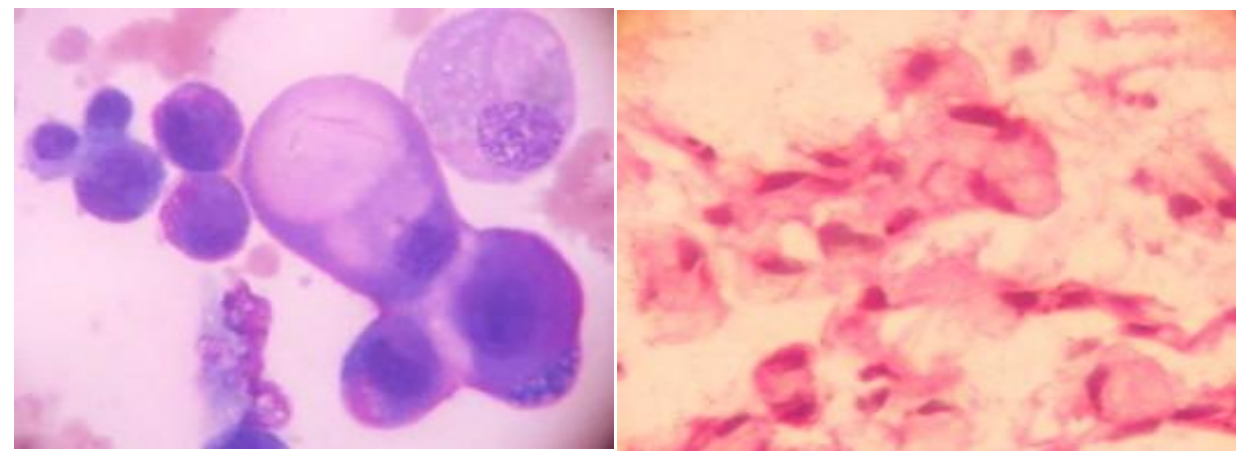

Fig-3: (a): Smears showing signet ring cells; Peritoneal fluid (Leishman stain, $100 \mathrm{X}$ ). (b) Cell block showing signet ring cells; Peritoneal fluid (H\&E stain, 40X)

In pericardial fluids, out of the 5 cases, 3 cases had predominantly lymphocytes and the other had mixed inflammatory cells. Table-2 shows efficacy of centrifuged smears with cell block in detecting malignant cells.

Table-2: Comparision of smear versus cell block in various fluids

\begin{tabular}{|l|l|l|l|l|l|l|}
\hline Cellularity & \multicolumn{2}{l|}{ Pleural fluids } & \multicolumn{2}{l|}{ Peritoneal fluids } & \multicolumn{2}{l|}{ Pericardial fluids } \\
\hline & Cytosmears & Cell block & Cytosmears & Cell block & Cytosmears & Cell block \\
\hline Lymphocytes & 75 & 76 & 12 & 12 & 03 & 03 \\
\hline Neutrophils & 11 & 11 & - & - & - & - \\
\hline Mixed inflammatory cells & 14 & 16 & 04 & 05 & 02 & 02 \\
\hline Blood elements & 3 & 03 & - & - & - & - \\
\hline Mesothelial cells & 3 & 03 & 03 & 03 & - & - \\
\hline Malignant cells & 11 & 13 & 02 & 03 & - & - \\
\hline Suspicious of malignancy & 2 & - & 01 & - & - & - \\
\hline Scant cellularity & 3 & - & 01 & - & - & - \\
\hline Total & 122 & 122 & 23 & 23 & 05 & 05 \\
\hline
\end{tabular}


In this study most of the patients are clinically diagnosed as pleural effusion with $44.26 \%$ followed by tuberculosis with $24.59 \%$, empyema with $9.83 \%$, malignancy with $10.65 \%$, cirrhosis of liver with $3.27 \%$, alcoholic liver disease with $3.27 \%$, congestive heart failure with $3.27 \%$, pneumonia $0.81 \%$.

Most of the patients of peritoneal fluids are clinically diagnosed as peritoneal effusions with $56.52 \%$, alcoholic liver disease with13.04\%, tuberculosis with $8.69 \%$, portal hypertension with $8.69 \%$, malignancy with $8.69 \%$

\section{DISCUSSION}

In the present study body cavity effusions are studied by using a comparative approach of routine cytosmears and cell block technique of pleural, peritoneal and pericardial fluids. Out of 190 cases of various fluids received, 150cases were studied and analysed. Remaining cases were excluded as the material obtained was inadequate for cell block preparation. In the present study, the predominant lesion detected in the various fluids was inflammatory $134(89.33 \%)$ while malignancy was detected in $16(10.66 \%)$ of the cases. One of the pleural fluid cell block case showed Microfilaria (WucherariaBancrofti), which was missed on cytosmears.

The most common site of effusion was pleural, followed by peritoneal and pericardial effusion. Our results correlated with the studies done by Sumitha M P et al., [7], Nathan et al., [8], Meenu Thapar et al., [9], FootNc et al., [10] and Murphy et al., [11], van de Molengraft et al., [12], Khan K et al., [13] and Sears \& Hajdu [14].

In the study done by Stonifer et al., [15], Sherwani R et al., [16], James R. Hallman et al., [17] and S. N. Booth et al., [18] the most common site of effusion was peritoneal, followed by pleural and pericardial effusions. These results differed with our study which may be explained by the preponderance of females presenting with ascites in their studies.

In the present study the predominance of pleural fluids can be explained by the high prevalence of tuberculosis in the region of our study and lymphocyte rich effusion was noticed in 90 cases, among these 32 were tuberculosis.

Spieler et al., observed the cytological features of tuberculous pleural effusion with moderate to high cellularity and predominance of lymphocytes [19].

In a study done by Sujathan K et al., [20], 85 samples of pleural and ascitic fluid were examined over a period of 10 months and they concluded that out of 85 samples, $63(74.12 \%)$ were inflammatory and $21(25.88 \%)$ were malignant. In the present study, out of 134 inflammatory cases 11 cases $(8.20 \%)$ were of acute inflammation, $90(67.16 \%)$ cases were found cytologically to be consistent with diagnosis of chronic inflammation, 21(14\%) cases were with mixed inflammatory cells, $3(2.23 \%)$ cases were found with blood elements, 6 cases $(4.47 \%)$ were showing reactive changes

In a study done by Nair et al., [21] out of 171 samples, majority were pleural fluid $78 \%$ (133samples). Ascitic fluid comprised only 22\% (38 samples). Of the total samples, $44 \%$ were malignant effusions and $47 \%$ were reactive effusions. Out of the 75 malignant effusions, 15(20\%) were ascetic fluids and $60(80 \%)$ were pleural fluids. Out of the total 81 samples of reactive effusions $74 \%$ were pleural effusion

Out of 150 cases studied by Archana et al., [5], $39(26 \%)$ were positive for malignancy by cell block method, while by routine method only 29 samples were reported as positive for malignant cells. Thus it was found that there was significant difference between the results obtained by direct smears method and cell block method.

Table-3: Comparison of the diagnostic yield of smear versus cell block in various studies

\begin{tabular}{|l|l|l|l|}
\hline & Achana et al., & Sujathan K et al., & Present study \\
\hline Total cases & 150 & 85 & 150 \\
\hline Inflammatory & 77 & 63 & 134 \\
\hline Positive for malignancy on smear & 29 & 19 & 13 \\
\hline Unsatisfactory/negative on smear & 10 & 2 & 3 \\
\hline Positive for malignancy on cell block & 39 & 21 & 16 \\
\hline
\end{tabular}

In the present study, out of 150 cases, 16 cases of malignancy were detected by using cell block method, while by using routine cytosmears, only 13 cases were diagnosed as malignant. Thus the use of cell block increased the diagnostic yield of malignancy from 13 to 16 samples showed $10 \%$ more diagnostic yield in cell block technique, consistent with the $12 \%$ increase reported by Richardsonet al., [22], Thapar et al., [3].

\section{CONCLUSION}

Cell block method is an excellent complementary tool for improving cytodiagnosis in effusions. Pleural fluids accounted for the majority of the effusion fluids. Majority were in the age group of 41-60years. Inflammatory effusions out numbered the malignant cases. Among the inflammatory effusions lymphocytic predominance is noted in majority of 
cases. Malignant pleural effusion was more common in males, the primary tumor was in the lung. Malignant ascites was more common in females, with the primary lesion in the ovary. Cell block technique increased the diagnostic efficacy by $6.5 \%$ when compared to cytosmears. We conclude that the cell block technique when used as an adjuvant to routine smear examination increases the diagnostic yield because of availability of more material for evaluation and better preservation of the cytoarchitectural pattern.

\section{REFERENCES}

1. Kumar V. Acute and chronic inflammation. In Robbins and Cotran Pathologic Basis of Disease. 8th edition. Edited by Kumar V. Philadelphia, Saunders Elsevier, 2010, 67.

2. Marluce B. SCD, FIAC, FASCP, David C Wilbur, Comprehensive Cytopathology. $3^{\text {rd }}$ edition. Saunders. 2008; 515.

3. Thapar M, Mishra RK, Sharma A, Goyal V, Goyal V. Critical analysis of cell block versus smear examination in effusions. J Cytol. 2009; 26:60-4.

4. Svante RO, Gregory FS, Darrel W. Fine Needle Aspiration Cytology, 5th edition. Edinburgh. Churchill Livingstone; 2012:15

5. Archana K. Bodele, Parate N, Wadadekar A, Bobhate SK, Munshi MM. Diagnostic utility of cell block preparation in reporting of fluid cytology. Journal of Cytology. 2003; 20(3):133135.

6. John BH. Clinical Diagnosis and Management by Laboratory Methods. 21th edition. Saunders; 2008: 441.

7. Sumitha MP, Niveditha SR, Tejaswi K. Cell Block or Centrifuged Smear: A Comparative Study from a Tertiary Care Center.

8. Nathan NA, Narayan E, Smith MM, Horn MJ. Cell block cytology: improved preparation and its efficacy in diagnostic cytology. American journal of clinical pathology. 2000 Oct 1;114(4):599-606.

9. Thapar M, Mishra RK, Sharma A, Goyal V, Goyal V. Critical analysis of cell block versus smear examination in effusions. Journal of cytology/Indian Academy of Cytologists. 2009 Apr;26(2):60-64.

10. Foot NC. Identification of types and primary sites of metastatic tumors from exfoliated cells in serous fluids. Am J Pathol. 1954; 30:661-677.
11. Murphy WM, Alan BP. Determination of primary site by examination of cancer cells in body fluids. Am J Clin Pathol. 1972; 18:479-488.

12. Van de Molengraft FJ, Vooijs GP. The interval between the diagnosis of malignancy and the development of effusions, with reference to the role of cytologic diagnosis. Acta cytologica. 1988;32(2):183-187

13. Khan N, Sherwani RK, Afroz N, Kapoor S. Cytodiagnosis of malignant effusion and determination of primary site. Journal of Cytology. 2005; 20(3):107-110.

14. Sears D, Hajdu SI. The cytologic diagnosis of malignant neoplasms in pleural and peritoneal effusions. Acta cytologica. 1987;31(2):85-89.

15. Stonesifer KJ, Xiang JH, Wilkinson EJ, Benson NA, Braylan RC. Flow cytometric analysis and cytopathology of body cavity fluids. Acta cytologica. 1987 Mar 1;31(2):125-30.

16. Sherwani R, Akhtar K, Naqvi AH, Akhtar S, Abrani A, Bhargava R. Diagnostic and prognostic significance of cytology in effusions. Journal of cytology. 2005; 22(2):73-77.

17. Hallman JR, Geisinger KR. Cytology of fluids from pleural, peritoneal and pericardial cavities in children. A comprehensive survey. Acta Cytol. 1994; 38(2):209-217.

18. Booth SN, Lakin G, Dykes PW, Burnett D, Bradwell AR. Cancer associated proteins in effusion fluids. J Clin Path. 1977; 30:537-540.

19. Speiler P. Cytological diagnosis of tuberculosis in pleural effusion. Acta Cytol. 1979; 23:374-379.

20. Sujathan K, Kannan S, Mathew A, Pillai KR, Chandralekha B, Nair MK. Cytodiagnosis of serous effusions: A combined approach of morphological features in Papanicolaou and MGG stained smears and a modified cell block technique. Journal of cytology. 2000; 17(2):89-95.

21. Nair GG, Manjula AA. Comparative study of cellblocks \& routine cytological smears of pleural \& peritoneal fluids in suspected cases of malignancy. Indian Journal of Pathology and Oncology. 2015 Jul 15;2(2):61-8.

22. Richardson HL, Koss LG, Simon TR. Evaluation of concomitant use of cytological and histological technique in recognition of cancer in exfoliated material from various sources. Cancer. 1955; $8: 948-50$. 